\title{
Nigeria's E-Waste Management: Extended Producer Responsibility and Informal Sector Inclusion
}

\author{
Woggsborg A and Schröder $\mathrm{P}^{*}$ \\ Institute of Development Studies, United Kingdom
}

*Corresponding author: Schröder P, Institute of Development Studies, Library Road, Brighton BN1 9RE, United Kingdom, Tel: +44 (0)1273 606261, E-mail: p.schroeder@ids.ac.uk

Citation: Woggsborg A, Schröder P (2018) Nigeria’s E-Waste Management: Extended Producer Responsibility and Informal Sector Inclusion. J Waste Resour Recycl 1(1): 102. doi: 10.15744/2766-5887.1.102

Received Date: May 19, 2018 Accepted Date: August 26, 2019 Published Date: August 28, 2019

\begin{abstract}
This paper explores the emerging role of the private sector and public-private partnerships for e-waste management in the developing world. We use a combination of two conceptual frameworks, the triple bottom line approach and the sustainable livelihoods approach, to analyze the case study of the Extended Producer Responsibility (EPR) programme in Nigeria, which was launched in 2016. The sustainable livelihoods approach has been adopted in international development for over two decades, but so far it has not been applied for inclusion of informal sector workers in e-waste. Our findings illustrate how the financial and environmental bottom lines have already received considerable attention during the development of the Nigerian EPR programme, but that the social elements, in particular informal sector inclusion, have received less attention. Consequently, based on proven practices of the sustainable livelihoods approach, this paper identifies opportunities and provides recommendations as to how the international and national private sector players and government agencies involved in Nigeria's e-waste EPR programme can establish a social engagement model to support inclusion of the informal sector. This model would not only help meet the financial and environmental bottom lines, but also address the social bottom line to improve livelihood outcomes for informal e-waste recyclers.
\end{abstract}

Keywords: E-Waste; Extended Producer Responsibility; Nigeria; Sustainable Livelihoods Approach

\section{Introduction}

Electric and electronic waste (e-waste) is growing at a rate of $4 \%$ annually globally and e-waste management and recycling in developing countries is emerging as a major development challenge with alarming proportions $[1,2]$. In this paper we explore the connections and potential synergies between public-private e-waste recycling approaches, extended producer responsibility (EPR) programme, and the effects it has on people's wellbeing and livelihoods [3]. Of special interest are poor and marginalised groups who are involved in informal e-waste recycling to generate income and rely on it for their daily survival.

The links between e-waste recycling and the environment have been readily researched within the circular economy discourse both the potential benefits of improved resource efficiency and environmental harms [4-8]. In this paper we aim to broaden the discussion to include elements of how e-waste recycling affects people's livelihoods and aim to show how EPR programmes implemented through public-private partnerships can address social issues. The paper also touches upon the financial aspects of e-waste recycling within an EPR framework as mobilizing multilateral development finance is required to address e-waste issues in developing countries. An important aspect that we explore is to what extent the economic, environmental, and social aspects of e-waste recycling can all be met within the same framework.

We do this by combining the triple bottom line approach used in business with a sustainable livelihoods approach from development studies, with the aim to put stronger emphasis on the social pillar [9]. We also explore the role of business as a development actor by juxtaposing two common perceptions of their role within the development discourse, namely that of the "do more business" and "do less harm" approaches. This framework is used to analyze the Nigerian EPR programme for e-waste as a case study, and to identify opportunities for the inclusion and formalization of the informal e-waste sector. Based on the findings of the Nigerian EPR programme for e-waste, where the financial considerations for have already been covered by the parties involved, our primary research objective is to explore the social elements in greater depth. We aim to show that an engagement model for the inclusion of the informal sector could lead to a positive result on the livelihoods of those currently involved in the informal recycling of e-waste in Nigeria [10].

\section{The global context of E-waste management}

E-waste has become a growing problem worldwide and has received increased attention from NGOs, governments, multilateral 
organizations and the private sector. Some of the key drivers for the growth of e-waste are rapid product innovation, minimization and planned obsolescence, trends which caused e-waste generation estimates in 2014 to be over $41.8 \mathrm{Mt}$ (Million Metric Tons), and 2018 forecasts to be $49.8 \mathrm{Mt}$ globally [11]. E-waste for developing countries can be viewed as both an opportunity and a risk - on the one hand, e-waste has numerous valuable components which, if recycled properly, can be a viable source of income and reduce reliance on virgin materials [12]. On the other hand, due to the hazardous nature of the materials in WEEE and their potential to produce harmful by-products during recycling, improper recycling poses a real threat to the environment and people's health [13]. Furthermore, not all elements of WEEE are profitable when recycled [14]. This means that subsidies are often required to make some aspects of e-waste recycling profitable, and has led to numerous policies that have sought to provide such subsidies in order to tackle the growing problem of e-waste [15]. There is increasing recognition that an integrative approach to e-waste is required that not considers technical solutions and the economic viability, but also cultural norms and political planning to ensure social and practical acceptance of e-waste recycling [16]. This is particularly relevant regarding the inclusion of informal e-waste collectors and recyclers. Through integrative municipal policy approaches and programmes offering training to informal recyclers and improving the existing recycling facilities, e-waste recycling can be optimized and formalized [17].

\section{Extended Producer Responsibility for e-waste}

In the context of the circular economy and e-waste management, extended producer responsibility (EPR) has received renewed attention. EPR involves the extension of a producers' financial and/or physical responsibility for its product to the post-consumer stage of the product's life cycle [18]. One of the ways in which the circular economy has manifested itself in practice is through EPR programmes. For example, a fact sheet published by the European Organization for Packaging and the Environment (2015) noted that in the EU alone, 25-member states had EPR programs and $€ 1.3$ billion in fees were paid by producers towards these schemes annually. However, it is not only in the EU that these programs are being implemented. The Organization for Economic Co-operation and Development (OECD) published guidelines on EPR programs in 2001 (2016 [updated version]) which sparked a boom in the adoption of EPR policies globally, including Latin America, North America, Asia, and to a lesser extent Africa [19]. One of the earliest examples of EPR in Africa is the South African scheme which began in 2010 with the Nigerian EPR programme being established in 2016 [20].

Gupt and Sahay have outlined two broad categories of EPR policy tools with respect to how the policies direct companies to engage with their responsibility for their products [21]. On the one hand, there is the product take-back approach, which places a physical burden on the companies. Examples of these approaches include the product take-back mandate and recycling rate targets, voluntary product take-back mandate and recycling rate targets, and mandatory take-back and targets with a tradable recycling scheme. These examples of physical burdens all share the common factor that they place the responsibility of the end of life products back on the companies that produced them. On the other hand, there are the economic instruments, which place a financial burden on the companies in relation to the end of life products. Examples here include advanced recycling fees, recycling fee combined with recycling subsidy, Deposit Refund System (DRS), or upstream taxes. The core difference between the latter and the former is that the latter purely has a financial element, which means that the responsibility for the end-of-life products is a monetary issue rather than a physical burden. It is important to note that a given EPR policy may make use of a number of these and other tools to outline a policy that fits the countries needs given their contexts.

EPR programs have been studied in other developing country contexts with a focus on e-waste, and provide some insights relevant to the Nigerian context. One area which has received particular attention within the literature is Asia, which has seen a considerable increase of e-waste over the last decade [22]. In the case of Malaysia, the EPR provisions in the country's EPR policy were generic in nature without relevant regulations to enable its enforcement. An effective EPR would require the enactment of an EPR regulation in Malaysia [23]. One case study review of Vietnam points towards four key areas which need to be fixed in order to effectively implement and EPR programme - public awareness of the benefits and existence of e-waste recycling possibilities, improvements in infrastructure for e-waste treatment, supporting legislation, and better knowledge of the material flows within the e-waste system due to a heavy informal recycling presence [24]. Akenji et al. also highlighted the need for adequate infrastructure and institutional capacity in order to successfully implement the EPR programmes, through their research in a broader Asian contex [22]. While the above points are undoubtedly requirements for a successful implementation, a key point relating to the Nigerian context surrounds the informal sector. A review of China's EPR programme points towards the challenges faced by EPR systems with a strong informal recycling presence, as is seen in the Nigerian context [25]. Studies point toward a multitude of dilemmas as a result of informal recycling, ranging from unsafe practices to pollution of the environment, difficulties relating to the potential for over-reporting recycling numbers without a system to monitor the informal recyclers and check the claims [26]. In summary, the literature notes that there are a multitude of potential issues with EPR implementation for e-waste in a developing country context, and a core element that has been pointed out is the issues relating to informal recycling. Provides a summary of the main points of EPR instruments relevant for e-waste management (Table 1). 


\begin{tabular}{|c|c|}
\hline Product take-back & Economic instruments \\
\hline $\begin{array}{l}\text { Product take-back mandates and recycling rate targets: manufacturers/retailers } \\
\text { are mandated to take back their end of life products, along with setting } \\
\text { recycling targets. Producer responsibility organizations (PROs) are often set } \\
\text { up as a collective effort by an industry to meet these obligations (Widmer et } \\
\text { al, 2005) [8]. }\end{array}$ & $\begin{array}{l}\text { Advanced recycling fee ( } A R F \text { ): A tax imposed on the sale of the products to } \\
\text { cover recycling costs for the producers/retailers. The fee is unit based and } \\
\text { charged at point of sale, either separately or upstream and incorporated } \\
\text { into the final sale price. }\end{array}$ \\
\hline $\begin{array}{l}\text { Voluntary product take-back mandate and recycling rate targets: A non- } \\
\text { mandatory approach with no penalties for not meeting targets. }\end{array}$ & $\begin{array}{l}\text { Recycling fee combined with recycling subsidy: which uses the revenue } \\
\text { generated from either the ARF or post-consumption recycling fee to } \\
\text { subsidize the recycling process. Revenue generated can be used in several } \\
\text { ways. It is either used to subsidize the upstream producer's activity of } \\
\text { getting the waste recycled or cost of managing the waste including the } \\
\text { infrastructure cost. }\end{array}$ \\
\hline \multirow[t]{2}{*}{$\begin{array}{l}\text { Mandatory take-back and targets with a tradable recyclingScheme: building } \\
\text { on the product take-back mandate and recycling rate targets, this instrument } \\
\text { also allows for recycling credit trading among producers, in a similar fashion } \\
\text { to carbon trading. }\end{array}$} & $\begin{array}{l}\text { Deposit refund system (DRS): This instrument places a deposit on the } \\
\text { products sold, by combining the tax on the product consumption with a } \\
\text { rebate/refund when the end of life product is returned for recycling. }\end{array}$ \\
\hline & $\begin{array}{l}\text { Upstream taxes (1) Material Tax: A special tax imposed on materials that } \\
\text { are hazardous or difficult to recycle. The tax is set at a level that mimics the } \\
\text { cost of recycling. } \\
\text { Upstream Taxes (2) Upstream combination tax/subsidy: A tax paid by the } \\
\text { producers to subsidize the waste treatment. }\end{array}$ \\
\hline
\end{tabular}

Table 1: EPR instruments for e-waste management (Adapted from Gupt and Sahay, 2015) [21]

\section{The Nigerian context of E-waste}

Over the last decade, Nigeria has seen an exponential growth of e-waste in recent years and has consequently been dealing with the growing issues surrounding e-waste particularly in large cities such as Lagos [12,13]. Data on Nigeria's e-waste generation and imports is patchy. It is estimated that in 2010, Nigeria processed 440,000 tons of e-waste through both importing about 100,000 tons and domestically producing e-waste [11,13]. According to Balde et al., EU member states were the origin of around $77 \%$ of used electric and electronic equipment imported into Nigeria [1]. The growth of both imports and domestic e-waste generation requires new management approaches to divert e-waste from disposal with municipal waste in Nigeria [27]. Currently, the informal sector plays a dominant role in Nigeria's e-waste management. Data from 2010 indicates that roughly $80 \%$ of e-waste recycling is being done through informal recycling [13].

Already more than a decade ago, research by Osibanjo and Nnorom identified the need for effective management of e-waste in Nigeria and recommended the implementation of EPR programmes [5]. Examples of past regulations or acts in Nigeria that have sought to deal with e-waste include the Environmental Impact Assessment Act Cap E12, Harmful Waste (Special Criminal Provisions) Act Cap HI, 1988 and updated in 2004, The National Environmental (Electrical/Electronic Sector) Regulations 2011, The National Environmental (Sanitation and Waste Control) Regulation 2009, and the Guide for Importers of UEEE [28]. While these measures, primarily aimed at creating registries aimed at for example importers and recyclers of e-waste, have managed to repatriate about 14 containers and 12 trucks of E-waste there are still large gaps in their ability to effectively deal with e-waste [28]. Challenges with enforcement have meant that issues related to illegal imports, informal recycling, as well as poor formal recycling methods and the negative externalities thereof, still impact Nigeria's soil, water, air and people's wellbeing [29]. A major remaining concern is that treatment/recycling is being carried out by the informal sector with little or no knowledge of the environmental and health risks of improper recycling. The most recent efforts by the government, as well as a coalition of private sector actors, has seen the launch of an EPR programme which was launched in 2016, seeking to put more responsibility onto the importers, exporters, manufacturers, assemblers, distributors, and retailers whose products end up as e-waste [28]. The EPR programme, coordinated by the Nigerian National Environmental Standards Regulations Enforcement Agency (NESREA), has sought to set up regulations to address issues such as illegal imports of electronic goods and e-waste and a registration requirement for e-waste recyclers. The recent developments and a public-private cooperation model with the World Economic Forum for effective implementation of the EPR are discussed in the case study section.

\section{Methodology and conceptual framework}

The methods for collecting data and information for this paper is based on a narrative literature review and four interviews with international and national experts involved in the EPR programme in Nigeria's e-waste sector. Furthermore, it included participation in e-waste related events in Abuja, Nigeria, in November 2016 and November 2017. The conference presentations and discussions with conference participants further informed the paper and the case study of the EPR e-waste system.

\section{"Business as a development actor" in e-waste management}

\section{Doing more business}

In 1970, with the rise of corporate social responsibility (CSR) as a concept within the business world, Milton Friedman published 
a short essay in the New York Times Magazine with the title "A Friednzan (sic) Doctrine - The Social Responsibility of Business is to Increase its Profits" [30]. In his essay, Friedman argued that the sole responsibility of businesses is to increase its profits as its responsibilities are not towards greater society but towards its owners and shareholders. To keep this desire for profits in check, he argued it is the role of government to set the rules of the game that businesses play. Consequently, governments should set laws and taxes in a way that best meets the needs and desires of the population, and as such, so long as businesses operate within those legal boundaries and pay their taxes, then they are free to pursue their profits without any other responsibilities. Within contemporary development discourse, the sentiments of Friedman's 1970 essay are echoed by one of the three ways of viewing the role of business in development - the "do more business" approach. The World Economic Forum posted an article in 2014 which argued that the pursuit of profits is not as separate to issues surrounding a business as the words of Friedman might indicate [31].

A major push towards a broader understanding of "do more" has come from the concept of shared value creation [32]. The argument is that business is pursuing a narrow vision of value creation in that their focus is on creating short term shareholder value, at the cost of overlooking unmet market needs and long-term profits and success. Porter and Kramer link issues of broader social and environmental importance such as resource depletion, economic distress within communities and the viability of suppliers to successful business and profit generation [32]. This notion is further supported by research into how brand value can be built from engaging with for example humanitarian aid customer loyalty and a competitive advantage can be gained from engaging with CSR [33-35]. Consequently, contemporary discourse on the role of business in development from a "do more business" approach needs to encompass much more than a ruthless short-term pursuit of profits and situate businesses within their larger social contexts.

However, actions taken by firms, while admittedly working towards certain elements of long term sustainability, and operation, are heavily influenced by a need to fix profits in the short term. Not only is the focus on short term profits seen in margin pressured industries, but nearly all major corporations are facing pressure from shareholders to meet expectations for profits and consequently the reality is that companies seek tax loopholes and take risks where those affected by failure are not those benefiting, should the risk pay off [36,37]. The result is that while the rhetoric of "do more" business has changed to highlight the benefits for companies of implementing practices that encompass a broader understanding of value creation, the reality in practice is that due to pressure from, for example, shareholders, short term profit seeking plays a key role in corporate decision making.

\section{Doing less Harm}

A second understanding of the role of business within development is that by nature of their operations, businesses do harm and consequently should actively seek to limit the damage they do rather than encourage uncontrolled growth and pursuits of profits. The questions raised by this view are: why do businesses harm? What do they harm? What can be done to prevent it? One way to answer the first question, and the way in which this paper will view the origins of business doing harm is through market failures, in particular with relation to negative externalities [38]. An example of this within the e-waste context is due to the hazardous nature of the materials in WEEE and their potential to produce harmful by-products during recycling, improper recycling poses a real threat to the environment and peoples' health [13]. The second question is then, assuming negative externalities are one of the main drivers of why businesses do harm, what types of harm is it that is being caused? Two commonly cited types of harm caused by negative externalities are damage to the environment and human health [39]. Harm done by businesses to the environment and people through negative externalities is well documented. Reports such as the Global E-waste Monitor along with the e-waste country assessment for Nigeria have outlined the harm that e-waste can cause when not managed properly $[1,11,13]$. Ogungbuyi et al. noted the complex pattern of environmental harm caused by unsound recycling [13]. No statistics exist about the exact number of people affected by either the environmental or human health harms caused by unsound practices, as Manhart et al. note in their study of informal e-waste management in Lagos [12]. The data availability for e-waste in general is minimal for Nigeria, resulting in their study not being able to note even the contribution to the national economy by e-waste recycling. Common to both environmental and social harm caused by e-waste is that they are manifestations of negative externalities caused by businesses involved in the EEE value chains. Another type of harm, which occurs because of the harms mentioned above, is the economic burden of these harms. This economic burden can manifest broadly speaking in two different forms. One form is through damages to health caused by negative externalities, either directly or through water pollution, air pollution or other environmental harm, which are placing an otherwise unnecessary burden on healthcare systems. The other form is through future cleanup costs and restorative projects. Whether this is something that a company, governments, civil society or another actor is set to deal with, the economic burden of restoring the environment or simply mitigating harm from continued pollution through waste is the direct result of the negative externalities harm done to the environment. Consequently, negative externalities result from as markets that are not able to adequately factor in these harms through mechanisms such as prices, and the results are harm to the environment, human health, as well as an accompanying economic burden.

\section{Triple Bottom Line}

The discourse around "business as a development actor" includes a broader discussion of the role of business than simply shortterm profit seeking. This paper therefore proposes to use the triple bottom line approach as a framework for evaluating how the private sector could engage more actively with the informal sector within the Nigerian EPR programme. The concept of the triple bottom line was first voiced by John Elkington [40]. In its simplest form, it states that businesses should go beyond the traditional 
financial bottom line approach to doing business, and include an environmental and social bottom line. These lines would see businesses not only attempting to make profits, but also protect the environment and work towards the betterment of their workers and the people they affect. Since then, the concept has been taken up by a number of scholars, businesses, and organizations as a tool for evaluating performances of businesses [41]. However, the way in which the triple bottom line is operationalized is still a contested subject, and changes depending on the organization which is seeking to use it. A single framework of evaluation for the triple bottom line has yet to be established, as individual companies face different challenges in different contexts, consequently any adoption of the triple bottom line approach requires a degree of situational awareness to in order to establish a meaningful framework [42]. This is further supported by the Consolidated Set of GRI Sustainability Reporting Standards which provides a wide range of possible reporting measurements which firms can adopt in their own triple bottom line reporting frameworks, but do not provide a single altruistic framework [43].

Applying the triple bottom line not to a company, but to an public-private EPR programme within which private sector companies are involved, highlights that the companies involved in the Nigerian EPR programme have already gone to great depth in ensuring the financial viability and conducting a 12-month cost forecast. Furthermore, funding from external sources for the purpose of covering startup costs associated with the project have been secured through global funds which help to secure meet the financial bottom line of the project. Consequently, while the financial bottom line is a vital part of the triple bottom line, for the purposes of this paper little analysis will go into this aspect of the project as a whole as sufficient attention has been paid by the parties involved and external organizations to ensure this is met.

With regards to the environmental bottom line the paper will take a slightly more detailed analytical approach. On the one hand, programmes such as the Nigerian EPR programme, which seeks to reduce our reliance on virgin resources in line with the circular economy principles, inherently meet the environmental bottom line in some sense [44]. However, as the following section will show, the choice to use Scoones' sustainable livelihoods approach as an operationalization of the social bottom line allows for a simultaneous analysis of the environmental bottom line [9].

\section{Applying the Sustainable Livelihoods Approach to E-waste}

The social bottom line, the so far unaddressed by the Nigerian EPR programme, is the focus of the following discussion. The social element, or the inclusion of the prominent informal recycling sector in Nigeria, is an area where research could help shape the successful implementation of the programme. Consequently, we place emphasis on the social element through a sustainable livelihoods approach in order to provide a more specific and insightful analysis on the case of the Nigerian EPR programme.

Within the sustainable livelihoods discourse there exists a multitude of definitions employed by academics, policy makers and other professionals. The original definition of sustainable livelihoods was put forth by Chambers and Conway during the period when sustainable livelihoods began to become a prominent concept within development discourse [45]. The definition used by UK's Department for International Development (DFID) that has been successfully employed by both academics and practitioners within international development:

1) A livelihood comprises the capabilities, assets (including both material and social resources) and activities required for a means of living. A livelihood is sustainable when it can cope with and recover from stresses and shocks maintain or enhance its capabilities and assets, while not undermining the natural resource base [9].

Within this definition, Scoones highlights five key components that help to operationalize the definition. The first three components refer to the livelihoods part of the definition and links aspects of "work and employment with poverty reduction with broader issues of adequacy, security, well-being and capability" [9]. The subsequent two components look at the sustainability side of the definition. Here is where the sustainable livelihoods analysis also touches on the environmental bottom line as part of the definition explores the effect of the livelihood on the natural resource base, by having a dual natured take on sustainability - that both the livelihood itself and the resources it uses should be sustainable. The below table outlines the five components in more detail by looking at the individual meaning of the components in relation to e-waste.

The sustainable livelihoods approach has been applied to a wide spectrum of developmental challenges in various country settings, including on national and strategic level in Mongolia, Uganda and India to address issues such as land tenure, micro-finance, and modernization of agricultural production and livestock risk management which affect local livelihoods [59]. The following section will explore potentials of the sustainable livelihoods approach in the Nigerian e-waste EPR programme.

\section{Case Study - the Nigerian EPR programme for e-waste management}

The Nigerian EPR programme: In 2011, Hewlett Packard, Dell, Microsoft Mobile and Phillips got together around the common concern over the e-waste recycling issues in Africa [60]. The group, along with the World Economic Forum (WEF) have been conducting research and having discussions as to how they should approach this issue, as a result the "E-waste Solutions for Africa (The Alliance)" was established, initiating corporate e-waste initiatives in various African countries, including Nigeria [61]. Another key actor in the Nigerian EPR programme is the National Environmental Standards and Regulations Enforcement Agency (NESREA). NESREA is the regulatory body for e-waste in Nigeria amongst other things, and as such was a core local actor in 


\begin{tabular}{|c|c|c|}
\hline No. & Component & Description \\
\hline 1. & Creation of working days & $\begin{array}{l}\text { This component relates to the ability of a livelihood strategy to create gainful employment } \\
\text { for a certain portion of the year. Sen notes three aspects of employment - income (a } \\
\text { wage for the employed), production (employment providing a consumable output) and } \\
\text { recognition (where employment provides recognition for being engaged in something } \\
\text { worthwhile) [46]. In terms of the income/production aspects, various target levels have } \\
\text { been suggested, but } 200 \text { days a year appears to be widely used as a minimum level to create } \\
\text { a livelihood [47,48]. }\end{array}$ \\
\hline 2. & Poverty reduction & $\begin{array}{l}\text { Scoones highlights two approaches to measuring poverty reduction. On the one hand is the } \\
\text { quantitative measurement such as absolute poverty lines based on income or consumption } \\
\text { levels with their associated shortcomings and difficulties of measurement [49-51]. However, } \\
\text { he also points towards a qualitative approach offered by Jodha and Schaffer, how argue that } \\
\text { poverty reduction is often not adequately captured by numeric analyses [52,53]. We suggest } \\
\text { following a qualitative approach to this component as it allows for a more multifaceted } \\
\text { discussion of how different engagement models regarding e-waste reduce poverty of } \\
\text { informal recyclers. }\end{array}$ \\
\hline 3. & Well-being and capabilities & $\begin{array}{l}\text { Scoones borrows from Chambers and Sen in his definition of well-being and capabilities } \\
\text { [54-57]. This paper draws on this key concept for the purpose of operationalizing well- } \\
\text { being for the e-waste recycling context. Well-being can be defined by a multitude of criteria } \\
\text { such as self-esteem, security, happiness, stress; vulnerability, power, exclusion, as well as } \\
\text { more conventionally measured material concerns [58]. }\end{array}$ \\
\hline 4. & $\begin{array}{l}\text { Livelihood adaptation, } \\
\text { vulnerability and resilience }\end{array}$ & $\begin{array}{l}\text { The essence of these criteria is that given a shock or stress to the livelihood it should } \\
\text { not go away completely, but be resilient. Taking the E-waste sector as an example, the } \\
\text { livelihoods around e-waste recycling should be resilient in the face of market price changes } \\
\text { for recyclables, or fluctuations in the amount of e-waste coinciding with new models or } \\
\text { other factors that impact the level of e-waste. Consequently, this component will also be } \\
\text { a qualitative measure and will look at the extent to which a given set up allows for the } \\
\text { buffering of various potential shocks and stresses to the livelihood. }\end{array}$ \\
\hline 5. & $\begin{array}{l}\text { Natural resource base } \\
\text { sustainability }\end{array}$ & $\begin{array}{l}\text { Scoones' original interpretation of sustainable livelihoods was in relation to rural } \\
\text { livelihoods where livelihoods were largely reliant on natural resources and consequently } \\
\text { he included this measure in his conceptualization of a sustainable livelihood. This paper } \\
\text { views e-waste and the recycling there of in a similar light in that livelihoods around e-waste } \\
\text { recycling/reuse or otherwise inclusion in the circular economy, reduces our reliance on } \\
\text { virgin materials and consequently has an impact on natural resource base sustainability. } \\
\text { While as discussed above, it is almost inherent that livelihoods in this sector have a positive } \\
\text { impact on the natural resource base, the way in which materials are recycled and the extent } \\
\text { to which less profitable aspects of E-waste can be recycled through financial instruments in } \\
\text { the EPR scheme differ. Consequently, the way in which the formalization of the informal } \\
\text { sector takes place can have differing degrees of positive impact on the natural resource base, } \\
\text { and still remains a valid point of analysis for the purpose of this paper. }\end{array}$ \\
\hline
\end{tabular}

Table 2: Five key components of sustainable livelihoods and adoption to Nigerian e-waste ERP (adapted from Scoones 1998, pp. 5-7) [9]

the discussions surrounding, and implementation of, the EPR program. The WEF also established the accelerating the Circular Economy Platform, which through involvement of powerful actors within the e-waste circle such as the Executive Director of UN Environment, has sought to catalyze circular economy projects. These actors, along with a broader network enabled through the WEF's involvement, have worked with the government of Nigeria to implement an EPR program which designed policies that were passed in 2016.

The EPR program in Nigeria has consequently come about through collaboration between private, public and third sector organizations and is a comprehensive model that seeks to optimize the benefits that recycling can bring. The E-waste Alliance Model is a complex and multifaceted model but a summary of its main components can be outlined. The model at its core is based on incentivizing the collection of all e-waste, including the non-valuable or "less profitable materials". The logic behind this is rooted in the fact that over $80 \%$ of Nigeria's e-waste is recycled by the informal sector, which means that unless the nonvaluable parts are made valuable through an incentive that the informal sector can take advantage of, then a lot of the e-waste will be recycled sub-optimally, or not at all. The system created to meet this is based on the formation of a Producer Responsibility Organization (PRO). This organization will be responsible for subsidizing the materials reported to be recycled, and is funded by a Minimal Collection Incentive (MCI) which the EEE producers pay to the organization. Through the network enabled by the WEF's involvement the initial funding for setting up this PRO and other costs for the project will be part funded by the Global Environment Facility (GEF) which has "confirmed the relevance of the project to its mandate and has expressed interest in funding the project as part of the current GEF 6 cycle, mobilizing funds before the end of the year" [60]. An important note for the system, and to counter some of the shortcomings on working within a system with heavy informal recycling, is that the only people able to take advantage of the subsidies provided by the PRO are registered recyclers [62-67]. Therefore, in order to truly take a triple bottom line approach to this, a socially sustainable way of formalizing the informal sector is essential for the programme to not exclude those whose livelihoods already rely on e-waste recycling (Figure 1). 


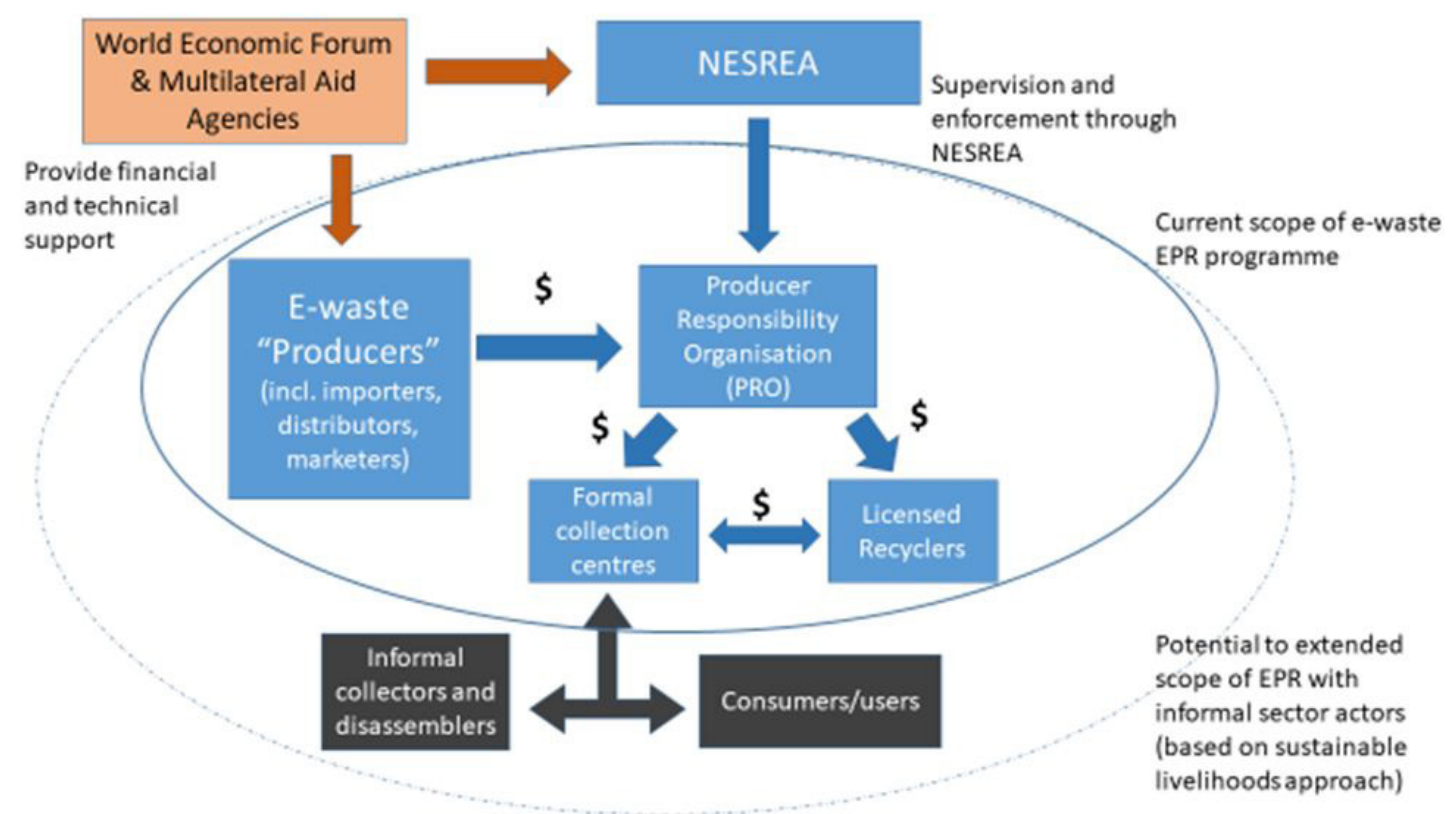

Figure 1: Nigeria's current EPR framework with potential for informal sector inclusion

\section{Discussion}

\section{Options for combining sustainable livelihoods approaches and EPR programmes}

Through the analysis the strengths and weaknesses of the current Nigerian EPR programme and the case study have been shown in light of the sustainable livelihoods framework. A core finding is that the current EPR model is not able to completely satisfy all the criteria, in particular the social aspects. Therefore, this paper recommends approaching the informal sector in Nigeria through a formalization approach which integrates sustainable livelihood criteria into the EPR. The informal sector can gain benefits particularly within well-being and capabilities as well as set up a strong base for further engagement with the informal sector in relation to training, and other employment. Along with this system a special interest group or advocacy group should be established to work with the now formalized informal sector to give them a voice and increased recognition. Alongside these two actions, a focus on establishing e-waste recycling centers with a supply chain approach that includes the newly formalized informal sector should be supported. This integrated approach would allow the EPR program to meet the social aspect of the triple bottom line approach, in line with the sustainable livelihoods framework.

The findings in this paper have opened up avenues for future research to build on the above analysis and results. In particular, more research should investigate how to fund sustainable e-waste recycling projects such as the EPR case study. Without external funding or financing from multilateral aid agencies such as GEF, NGOs, private sector, or government, projects such as this would not exist and the factors that enable such funding are yet to be fully understood. Furthermore, the Nigerian EPR case study presents a strong case for additional efforts to meet the social bottom line through informal sector inclusion. Further research is needed into other models from other developing country contexts in order to fully explore the best way to meet the social bottom line for e-waste management.

\section{Conclusion}

This paper explored how the private sector, which has become involved in supporting the Nigerian EPR scheme for e-waste, could approach the EPR implementation from a triple bottom line approach. The research showed that the financial and environmental bottom lines have already received sufficient attention by the actors involved, but that the social side has not received sufficient attention. Since the informal sector still accounts for the largest share of Nigeria's e-waste recycling, the effectiveness of the EPR programme will depend to a large degree on successful inclusion of informal recyclers. The findings from the analysis show that in order to meet the social bottom line, an integrative approach needs to be used and a wider range of informal stakeholders included in the implementation of the EPR. Additional interventions adopting a sustainable livelihoods approach for vulnerable groups could be a potential way forward. Through the explicit inclusion of informal sector, the Nigerian EPR programme would able to meet a triple bottom line - a sound financial bottom line, which the companies require to do more business, as well as a positive effect through reducing their environmental impact and preventing social harm. 


\section{References}

1. Baldé CP, Forti V, Gray V, Kuehr R, Stegmann P (2017) The Global E-waste Monitor - 2017, United Nations University (UNU), International Telecommunication Union (ITU) \& International Solid Waste Association (ISWA), Bonn/Geneva/Vienna.

2. Premalatha M, Abbasi T, Abbasi SA (2014) the Generation, Impact, and Management of E-Waste: State of the Art. Crit Rev Env Sci Technol 44: $1577-678$.

3. European Organization for Packaging and the Environment (2015) Factsheet: Extended Producer Responsibility (EPR) for used packaging.

4. Hischier R, Wäger P, Gauglhofer J (2005) Does WEEE recycling make sense from an environmental perspective? The environmental impacts of the Swiss takeback and recycling systems for waste electrical and electronic equipment (WEEE). Environ Impact Assess Rev 25: 525-39.

5. Osibanjo O, Nnorom I (2007) The challenge of electronic waste (e-waste) management in developing countries. Waste Manag Res 25: 489-501.

6. Nnorom I, Osibanjo O (2008) Overview of electronic waste (e-waste) management practices and legislations, and their poor applications in the developing countries. Resour Conserv Recycl 52: 843-58.

7. Robinson BH (2009) E-waste: An assessment of global production and environmental impacts. Sci Total Environ 408: 183-91.

8. Widmer R, Oswald-Krapf H, Sinha-Khetriwal D, Sccnellmann M, Boni H (2005) Global perspectives on e-waste. Environ. Impact Asses Rev 25: 436-58.

9. Scoones I (1998) Sustainable Rural Livelihoods a Framework for Analysis. IDS Working Paper 72, IDS, Brighton, UK.

10. Agamuthu P (2010) The role of informal sector for sustainable waste management. Waste Manage Res 28.

11. Baldé CP, Wang F, Kuehr R, Huisman J (2015) The global e-waste monitor - 2014, United Nations University, IAS - SCYCLE, Bonn, Germany.

12. Manhart A, Osibanjo O, Aderinto A, Prakash S (2011) Informal e-waste management in Lagos, Nigeria - socio-economic impacts and feasibility of international recycling co-operations, Final report of component 3 of the UNEP SBC E-waste Africa Project.

13. Ogungbuyi O, Nnorom I, Osibanjo O, Schluep M (2012) e-Waste Country Assessment Nigeria. e-Waste Africa project of the Secretariat of the Basel Convention, Nigeria.

14. D’Adamo I, Rosa P, Terzi S (2016) Challenges in Waste Electrical and Electronic Equipment Management: A Profitability Assessment in Three European Countries. Sustainability 8: 1-9.

15. Li J, Yang J, Liu L (2015) Development potential of e-waste recycling industry in China. Waste Manage Res 33: 533-42.

16. Ikhlayel M (2018) an integrated approach to establish e-waste management systems for developing countries. J Cleaner Prod 170: 119-30.

17. Fei F, Qu L, Wen Z, Xue Y, Zhang H (2016) How to integrate the informal recycling system into municipal solid waste management in developing countries: based on a China's case in Suzhou urban area. Resour Comserv Recycl 110: 74-86.

18. OECD (2004) Economic Aspects of Extended Producer Responsibility.

19. Fénérol C, Adams J (2001) Extended producer responsibility. Paris, France.

20. Department of Environmental Affairs South Africa (2010) Extended Producer Responsibility. National Waste Manag Strategy, South Africa.

21. Gupt Y, Sahay S (2015) Review of extended producer responsibility: A case study approach. Waste Manag Res 33: 595-611.

22. Akenji L, Hotta Y, Bengtsson M, Hayashi S (2011) EPR policies for electronics in developing Asia: an adapted phase-in approach. Waste Manag Res 29: 919-30.

23. Agamuthu P, Victor D (2011) Policy trends of extended producer responsibility in Malaysia. Waste Manag Res 29: 945-53.

24. Nguyen DQ, Ha VH, Eiji Y, Huynh TH (2017) Material Flows from Electronic Waste: Understanding the Shortages for Extended Producer Responsibility Implementation in Vietnam. Procedia CIRP 61: 651-6.

25. Cao J, Lu B, Chen Y, Zhang X, Zhai G, et al. (2016) Extended producer responsibility system in China improves e-waste recycling: Government policies, enterprise, and public awareness. Renewable Sustainable Energy Rev 62: 882-94.

26. Kojima M, Yoshida A, Sasaki S (2009) Difficulties in applying extended producer responsibility policies in developing countries: case studies in e-waste recycling in China and Thailand. J Mater Cycles Waste Manage 11:263-69.

27. Nnorom I, Osibanjo (2008) Electronic waste (e-waste): Material flows and management practices in Nigeria. Waste Manage 28: 1472-9.

28. Amachree M (2013) Update on E-waste Management Nigeria, Nigeria.

29. Sullivan J (2014) Trash or Treasure: Global Trade and the Accumulation of E-Waste in Lagos, Nigeria. Afr Today 61: 89.

30. Friedman M (1970) A Friednzan doctrine - The Social Responsibility of Business is to Increase its Profits, USA.

31. Allaire Y (2014) What is the role of business?

32. Porter M, Kramer M (2011) Creating Shared Value. Harvard Business Review 89: 62-77.

33. Steenkamp JB, Batra R, Alden DL (2002) How perceived brand globalness creates brand value. J Inter Bus Stud 34: 53-65.

34. Pérez A, Rodríguez del Bosque I (2014) An integrative framework to understand how CSR affects customer loyalty through identification, emotions and satisfaction.J Bus Ethics 129: 571-84.

35. Du S, Bhattacharya CB, Sen S (2011) Corporate social responsibility and competitive advantage: Overcoming the trust barrier. Manag Sci 57: 1528-45.

36. Otusanya OJ (2011) The role of multinational companies in tax evasion and tax avoidance: The case of Nigeria, Crit Perspect on Accounting $22: 316-32$.

37. Allen K (2015) Shell in Nigeria: The landmark oil case is a warning shot to multinationals, UK.

38. Helbling T (2012) Externalities: Prices Do Not Capture All Costs, Finance \& development.

39. Biglan A (2009) The role of advocacy organizations in reducing negative Externalities, J Organizational Behav Manage 29: 215-30.

40. Elkington J (1994) Towards the Sustainable Corporation: Win-Win-Win Business Strategies for Sustainable Development. California Manage Rev 36: 90-100.

41. OECD (2008) OECD Sustainable Development Studies Measuring Sustainable Production.

42. Thomas M, McElroy MW (2015) A Better Scorecard for Your Company's Sustainability Effort. Harvard Business Review, USA.

43. GRI (2016) Consolidated Set of GRI sustainability Reporting Standards 2016.

44. Ellen MacArthur Foundation (2015) Circular economy principles, UK.

45. Chambers R, Conway G (1992) Sustainable Rural Livelihoods: Practical concepts for the 21st century. 
46. Sen A (1975) Employment, Technology, and Development. Oxford: Clarendon Press, UK.

47. Lipton M (1983) Labor and poverty. The World Bank, USA.

48. Lipton M (1994) Growing points in poverty research: labour issues. International Institute for Labour Studies, Switzerland.

49. Ravallion M (1992) Poverty comparisons: a guide to concepts and methods. World Bank, USA.

50. Baulch R (1996) Neglected trade-offs in poverty measurement, IDS Bulletin 27: 36-43.

51. Greeley M (1994) Measurement of poverty or the poverty of measurement? IDS Bulletin 25: 50-7.

52. Jodha NS (1988) Poverty Debate in India: A Minority View. Econ and Political Weekly 23: 2421-5.

53. Schaffer P (1996) Beneath the poverty debate: some issues. IDS Bulletin 27: 23-35.

54. Chambers R (1995) Poverty and livelihoods: whose reality counts? IDS Discussion, Brighton: IDS.

55. Chambers R (1997) Responsible well-being - a personal agenda for development. World Dev 25: 1743-5.

56. Sen A (1984) Resources, Values and Development. Oxford University Press, Basil Blackwell, UK.

57. Sen A (1987) The Standard of Living. Cambridge: Cambridge University Press.

58. Chambers R (1989) Vulnerability, coping and policy. IDS Bulletin 20: 1-7

59. Carney D (2003) Sustainable livelihoods approaches: Progress and possibilities for change. Department for International Development, UK.

60. World Economic Forum (2017) Nigeria E-waste implementation plan 04.05 Public, World Economic Forum, Geneva.

61. Clancy H (2013) Dell Steps Up E-Waste Recycling With African Hub.

62. Council Directive 2002/96/EC of OF The European Parliament and of the Council 27 January 2003 on waste electrical and electronic equipment (WEEE). Official Journal of the European Union.

63. Directive 2012/19/EU of The European Parliament and of the Council 4th July 2012 on waste electrical and electronic equipment (WEEE).

64. European Commission (2017) Waste electronic equipment - Environment - European Commission.

65. Novo Nordisk (2017) TBL Quarterly no 2, Denmark.

66. OECD (2014) The State of Play on Extended Producer Responsibility (EPR): Opportunities and Challenges. OECD Publishing, Tokyo.

67. OECD (2016) Extended Producer Responsibility: Updated Guidance for Efficient Waste Management, OECD Publishing, Paris.

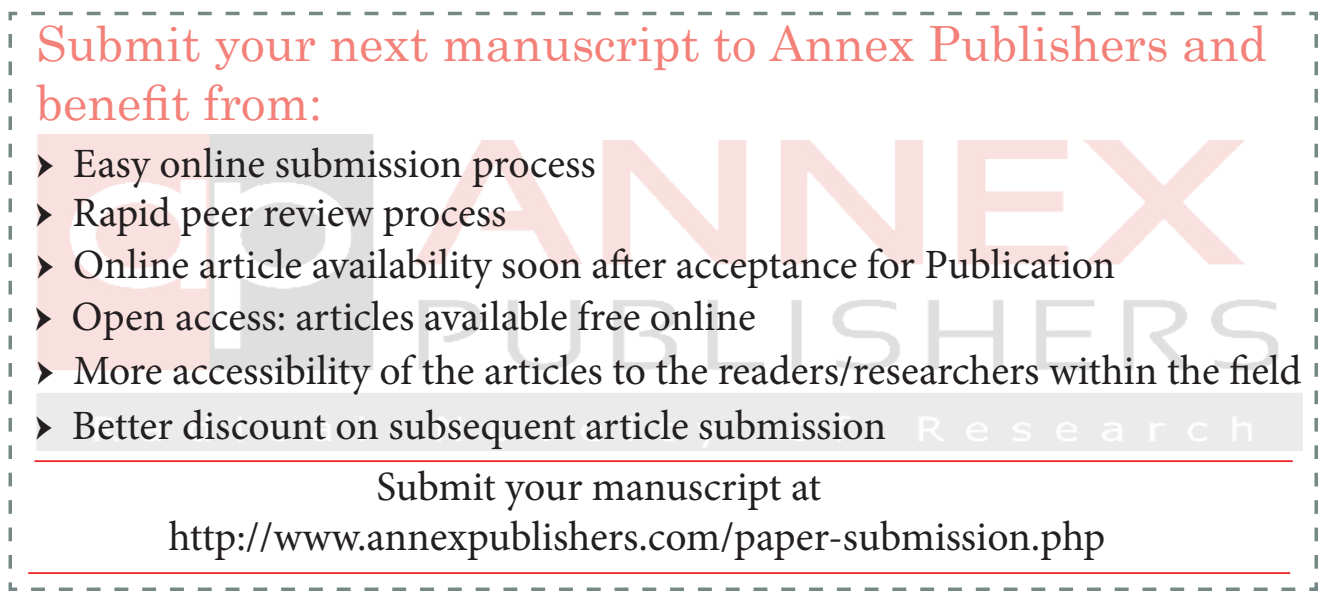

